\title{
LEXICAL AND SYNTAX FEATURES OF ENGLISH AND ARABIC LEGAL DISCOURSE: A COMPARATIVE STUDY
}

\author{
Hanem El-Farahaty, $\mathrm{PhD}$ researcher in \\ University of Leeds, UK \\ Assistant Lecturer, University of Mansoura, Egypt \\ Department of Arabic and Middle Eastern Studies \\ School of Modern Languages and Cultures \\ University of Leeds \\ LS2 9JT \\ UK \\ smlhesa@leeds.ac.uk \\ hmyelfarahaty@yahoo.com
}

\begin{abstract}
This paper discusses the common lexical and grammatical features of legal discourse in English and Arabic. ${ }^{6}$ The rationale behind this analysis is to compare and contrast the discourse of both languages, list the similarities and differences between them and come up with the most problematic areas in legal translation. It is worth mentioning that features of Arabic legal discourse have not been researched before, thus, I have taken the features of legal English as headlights according to which I will analyze the corpus of Arabic legal documents. These features, however, are not specific to one particular type of written language of the law. By type of language is meant the different types of legal texts such as legislations, contracts, official documents, court proceedings, etc. For this purpose, authentic samples of different English and Arabic legal documents have been consulted. These texts, obtained from law professionals, include private legal documents such as tenancy agreements, employment contracts, correspondences between solicitors and clients, reports to the court, birth certificates, and marriage certificates. Other documents include selected legislative and international documents. To this effect, the United Nations (UN) website, other translation books such as Mansoor (1965), Hatim, Shunnaq and Buckley (1995) are consulted.
\end{abstract}

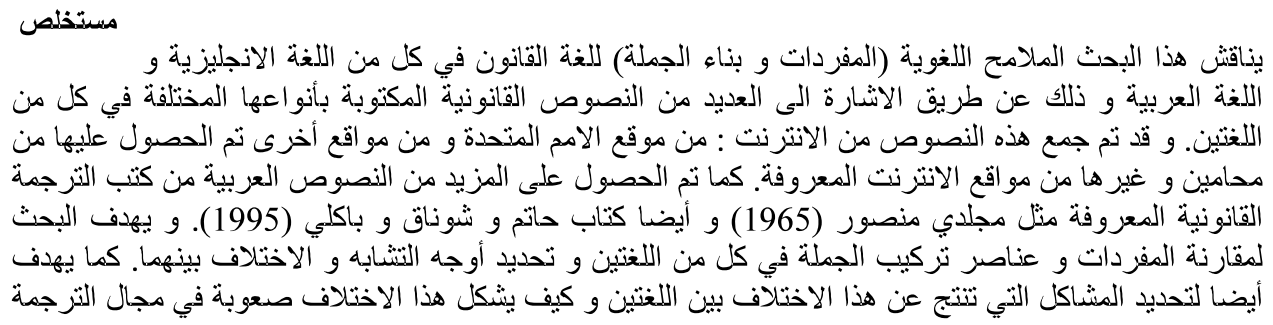

${ }^{6}$ Other textual and stylistic features are beyond the scope of this paper. 


\section{Comparative Legilinguistics 4/2010}

القانونية. و تجدر الاشارة الى أن هذا البحث بعد تمهيدا لدراسة أخرى عن مثاكل التزجمة القانونية في اللغنين الانجليزية و العزبية و كيف التعامل معها.

\section{Introduction}

Mellinkoff $(1963,3)$ defines the language of the law as 'the customary language used by lawyers and includes distinctive words, phrases, modes of expression, certain mannerisms of composition not exclusive with the profession but prevalent to have formed a fixed association'. For Goodrich (1987, 3), however, legal discourse is a linguistic register that can be defined in terms of its systematic appreciation of legally recognized meanings, accents, and connotations, and its simultaneous rejection of alternative and competing meanings and accents, forms of utterance and discourse generally, as extrinsic, unauthorized or threatening. I have found Šarčević's definition $(1997,9)$ of legal text as a 'communicative occurrence produced at a given time and place and intended to serve a specific function' as naïve due to the fact that each text is in fact a communicative occurrence and aims to achieve a pragmatic function. Schäffner (1997, 120) holds that 'it is usually the case that the source text (ST) itself fulfils a particular function in the source language (SL) community, at a particular place, addressed to a more or less specific audience with knowledge about the subject of the text and probable text-typological conventions.'

Most of the researchers who studied the language of law focused on written legal documents whereas spoken legal discourse was neglected until the advent of the 1970s. Nowadays, much work has been done on the oral genres of legal discourse such as court hearings, witness examination, and cross-examination. This is the specific area of forensic linguistics.

\section{Features of English and Arabic Legal Discourse}

As mentioned earlier, the richness of literature discussing the features of English Legal discourse ${ }^{8}$ lies in sharp contrast with the lack of reference books dealing with Arabic Legal discourse. That is why such study is challenging. For the Arabic Legal features, I have consulted some books on Arabic linguistics, Arabic stylistics as well as Arabic translation. My aim is to figure out the main features of Arabic in general, and see how much of these features apply to the language of legal Arabic. It is noteworthy that Modern Standard Arabic (MSA) will be the language variety used in the corpus of

\footnotetext{
${ }^{7}$ For more information about this genre of legal English, refer to: O'Barr, 1982; Conley and O’Barr, 1998; Gibbons, 2003; and Coulthard and Johnson, 2007.
}

${ }^{8}$ For English legal discourse, we have found the works of Mellinkoff (1963), Crystal and Davy (1969), Danet (1976, 1980), Erickson et al. (1978), Charrow and Crandal (1978), Charrow and Charrow (1979), Kittredge and Lehrberger (1982), Goodrich (1987), Alexy (1989), Sarcevic (1997), Trosborg (1997), Conley and O'Barr (1998), Garre (1999), Alcaraz and Hughes (2002), Asensio (2003), Haigh (2004), and Cao (2007) very helpful. 
documents under investigation. Also, examples from the Arabic corpus will be followed by their English translation.

\subsection{Lexical Features}

Legal discourse has its own 'legalese'; likewise, media discourse has its own 'journalese'. Goodrich $(1987,177)$ argues that 'legal vocabulary is primarily symbolic lexicon which places great stress upon the legal signifier or legal word as an entity in itself. It is a vocabulary of possibilities purportedly comprising a comprehensive system of meanings that are internal or latent within the lexicon itself'. Lexis in legal discourse can be generally divided into (i) 'technical words' (i.e. barrister, solicitor, court, and case law: a letter from a solicitor to a client), (ii) 'semi-technical' (i.e. assessment, enclose, compensation: correspondences between a solicitor and client); and (iii) 'every day vocabulary' (i.e. report, record, access, repair, examine, injury: correspondences between $a$ solicitor and client). These common features apply to English and Arabic legal discourse. Arabic, likewise, involves (i) 'technical words' such as (قدكمة / case), قضية) court); (ii) 'semi-technical' as in (دليل / نعويض' / evidence), compensation); and (iii)

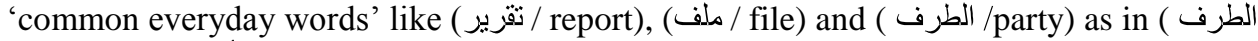
الدفاع) (الأول و الطرف الثاني (the first party and the second party) in contracts and agreements / the defence (the lawyer)), as is always the case in court hearings. These words are also used in non-legal contexts, for instance, 'الدفاع' in:

It is the right of each citizen to defend his freedom. (my translation)

$$
\text { حريته من حق كل مواطن الدفاع عن }
$$

Some Legal Arabic genres such as legislative and international legal Arabic share some lexical features with other Arabic genres such as diplomatic, political, and media Arabic. The following are examples of the occurrences of some phrases that cooccur in legal Arabic as well as in the three-pre-mentioned Arabic genres the first of which is taken from The Pact of the League of the Arab States:

(Mansoor 1965a, 9)

$$
\text { مسلح إستقلال الدولة أو سيادتها أو سلامة أر اضيها ، لفض النزاع ، إذا وقع اعثداء }
$$

The independence of the state, its sovereignty or its terroritial integrity, settlement of the dispute, if a military aggression takes place. (Mansoor 1965b, 4)

Other examples are cited in the preamble of The Arab Charter of Human Rights:

حق الامم في تقرير مصير ها ... ايمانا بسيادة القانون

... the right of nations to self-determination, ... believing in the rule of law.

It is also worthwhile to note that Arabic legal discourse shares other features of literary Arabic such as figures of speech. This proves what Gu $(2006,140)$ states about the roots of Arabic compared to English in the following quotation:

Whereas legal English adopted a Romanic vocabulary to build its legal (as distinct from literary) language, legal Arabic grew out of literary language and became more sophisticated with the development of its literary counterpart. In fact, there was neither a clear-separation between legal, religious, linguistic and literary Arabic nor an absolute division of labour between grammarians, theologians, and jurists in early Islam. 


\section{Comparative Legilinguistics 4/2010}

Metaphors occur in specialized language for some reasons given by Matulewska (2007, 130):

Metaphors are rather unusual in languages for special purposes because they introduce a certain lack of precision. However, they still may be found in legal discourse. Some of them enter into legal discourse because judges use them while performing their job, and others are a result of applying the same rules which govern the colloquial language to a language for special purposes. There are also metaphors which penetrate the language as literal translations from Latin metaphorical phrases e.g. nudum pactum resulted in a naked or nude contract ... it is very important for translators to be able to identify them and find their legal meaning in order to translate them successfully and to avoid discreditable translations. ${ }^{9}$

An example of the metaphoric nature of legislative texts is taken form the preamble of The Iraqi Constitution (2005):

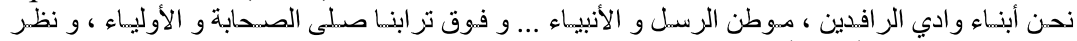

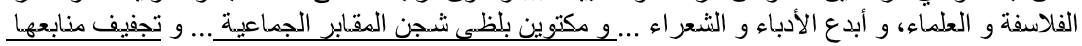

$$
\begin{aligned}
& \text {.... الفكرية }
\end{aligned}
$$

We, the people of Mesopotamia, the homeland of apostles and prophets ... Upon our soil the saints and companions of the prophet prayed, philosophers and scientists theorized, and writers and poets excelled ... and burnt by the flames of grief of the mass graves ... and drying out of its cultural and intellectual wells ...

The preamble of The Iraqi Constitution represents a masterpiece of the Arabic prose style which is alien to English legal discourse. For example, the above excerpt which is just a small quote a two-page long preamble contains alliteration, rhyme, parallelism, and metaphors as in the first instance: (مكتوبن بلظى شجن المقابز الجماعية) burnt by the flames of grief of the mass graves). This metaphor gives an image of the grief and sorrow as burning fire. It is also used to express a very complicated status of sorrow. The second phrase (تجفيف منابعها الفكرية / drying out of its cultural and intellectual wells ...) is also metaphoric because it talks of cultural and intellectual properties as wells which were dried out because of conflicts.

\subsubsection{Archaic, Latin and French Words}

Archaic words are known as 'the frozen patterns of language' according to Baker (1992, 63), or as 'routines' according to Hatim and Mason (1997, 190) . Legal English, is characterized by its old or 'antiquated language' Alcaraz varó and Hughes $(2002,5)$. These date back to the Anglo Saxons' old English and Middle English since the Norman Conquest in (1066 AD). The following examples are cited in the authentic corpus analyzed:

\footnotetext{
${ }^{9}$ It is important to point out that English legal discourse is also said to have metaphors for the same reasons given by Matulewska (2007:130). Examples of these are given by Alcarez and Hughes (2002:44): 'to stand mute by visitation of God'. In the corpus of English documents analyzed, no metaphors have been cited.
} 
This contract shall commence ... in accordance with provisions hereunder. (partnership contract)

Thereafter not to assign, sublet or part with possession ... (Tenancy Agreement)

Archaic words are so frequent in English as it keeps the reservoirs of register. Arabic legal discourse, on the other hand, does have few of them because it has so much higher tolerance that the cutting edge is not so clear between Arabic different registers. Similarly, Classical Arabic terms continues to exist in today's Modern Standard Arabic.

Examples of the continuation of such archaic words in Modern Standard Arabic are: (المذكور اعلاه - the aforementioned), (المعتبرة شزعام) - the legally capable), and (الولي) guardian). Not all the archaic words, however, continued to exist in Modern Standard Arabic. Examples of the words that are repeated in the legal documents published in the $17^{\text {th }}$ century Ottoman period are: (المسفور - the stated) and (المزبور - the aforementioned (Ebeid, and Young1976, 14 and 36 subsequently).

In the Middle Ages, the dominant language of the Church was Latin and since then the English language of the law is loaded with Latin words which are considered part and parcel of this language. Examples of the Latin words cited in the samples analyzed include: 'minor' (A Lawyer's Letter to a Client) which refers to a party in a case; 'bona fide' (A Partnership Contract, 20), which is used in UK legal context to mean 'in good faith'.

The Norman Conquest introduced many French words to English. These words include: 'Purchase', 'attorney', 'court', 'evidence', 'jury', 'judge', and 'verdict', and they survived in legal English till now (Mellinkoff 1963, 58). The samples also include few French words such as: 'court', 'evidence', and 'property' (Tenancy Agreement).

French and Latin words, are not characterizing features of Legal Arabic because it belongs to a different language family, i.e. the Semitic languages whereas English belongs to the Indo-European languages.

\subsubsection{Formal Words}

Legal English is characterized by its formal register. This formality stems from its specialty, function, and uniqueness which are expressed by fixed linguistic aspects. ${ }^{10}$

English legal discourse employs formal modes of address in formal contexts. Some of the expressions that are likely to occur are: 'your honour', 'your majesty' (in Courts); 'royal' (in a Decree by a Queen); 'master' (of a Minor in a Report to the Court), etc. The Following is The Enactment Formula of the Parliament of the UK:

WE, Your Majesty's most dutiful and loyal subjects, the Commons of the United Kingdom in Parliament assembled, towards raising the necessary supplies to defray Your Majesty's public expenses, and making an addition to the public revenue, have freely and voluntarily resolved to give and grant unto Your Majesty the several duties hereinafter mentioned; and do therefore most humbly beseech Your Majesty that it may be enacted, and be it enacted by the Queen's [King's] most Excellent Majesty, by and with the advice and consent of the

\footnotetext{
${ }^{10}$ Formality in English legal discourse can be expressed through modals. Examples of such formal expressions are enactment formulas, and certain utterances in marriage ceremonies.
} 


\section{Comparative Legilinguistics 4/2010}

Lords Spiritual and Temporal, and Commons, in this present Parliament assembled, and by the authority of the same, as follows:-

The above excerpt represents a high degree of formality which is exhibited along the whole text, namely, 'your Majesty most dutiful and loyal subjects', 'and do therefore most humbly beseech your Majesty', 'be it enacted by the Queen's [King's] most Excellent Majesty'. The text represents other features of legal English such as lexical doublets: 'freely and voluntarily', 'give and grant', 'advice and consent'; archaic words: 'hereinafter'; complexity of syntax as the whole text combines one non-completed sentence; nominalization: 'making an addition'; wh-deletion: 'duties hereinafter mentioned', 'in this present Parliament assembled'; and the use of 'same' as a pronoun.

Arabic legal discourse is also formal, yet, the way legal Arabic expresses such formality is widely different from English. In Arabic, formality is done through forms of address or honorary titles due to the diverse social, political and religious backgrounds in different Arab countries. Modes of address are one of the distinctive features of Arabic legal texts. They are, as Lataiwish $(1995,256)$, puts it 'expressions of courtesy and praise and tend to elevate and acknowledge the status of the person addressed, whereas in English 'mister' and 'sir', have an almost neutral honorific value.'

The following excerpt from The Pact of the League of Arab States -II introduces some of the titles used in a legal context. It should be mentioned that these titles are also initiated by the word (حضرة / hadrat) which is redundant, hence was omitted in the English rendition of the quotation:

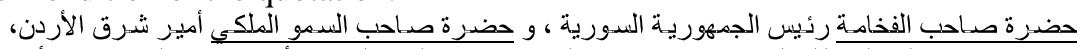

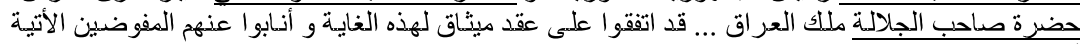

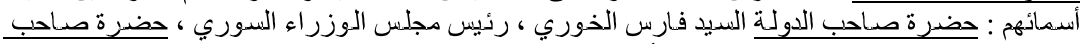

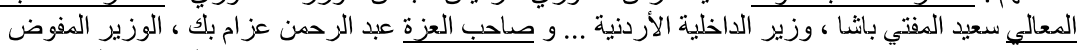

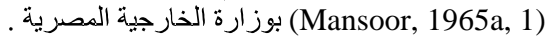

His Excellency the President of the Syrian Republic, His Royal Highness the Emir of Transjordan, His Majesty the King of Iraq, ... have agreed to conclude a pact to this effect and have delegated as their plenipotentiaries those whose names are given below: His Excellency Faris Al Khury, President of the Syrian Council of Ministers, His Excellency Said Al Mufti Pasha, Jordanian Minister of the Interior... His Excellency Abd Rahman Azzam Bey, Minister Plenipotentiary in the Egyptian Ministry of Foreign Affairs. (Mansoor, 1965b, 1).

Sometimes, introductory statements that portray high level of decorative pompous phrases are employed. Consider the following excerpt from one of the meetings of The Islamic Educational, Scientific and Cultural Organization (ISESCO):

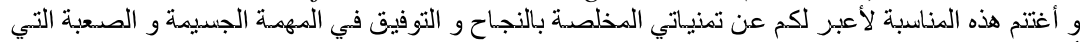

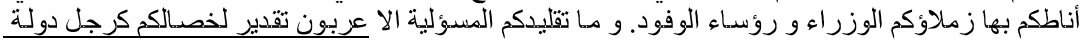

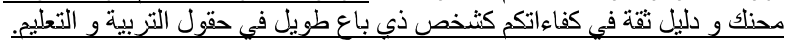

And I cease the opportunity to wish you every success in accomplishing the challenging and difficult task which has been entrusted to you by your colleague ministers and the heads of delegations. It is nothing but an appreciation of your 
qualities as a wise statesman and confidence in your skills and long experiences in the field of education. (my translation)

This type of decorative language distinguishes formality in Arabic from its counterpart in English which does not employ such highly pompous expressions. It is worth noting, however, that this is not a characteristic of official Arabic documents since these documents display most of the characteristics of English official documents.

A closer look at the above example reveals that the second person plural pronoun is used to address one person (second person singular) exemplified in ( لك / / $/$ / you; أن.اطكم بهـا زماؤكم الوزراء / has been entrusted to you (plural) by your (plural) colleague

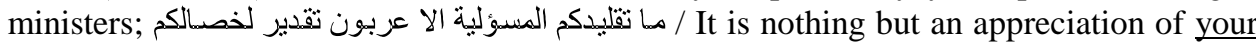
qualities). This honorific feature of legal Arabic also exists in formal letters such as a concluding remark of appreciation that reads (و / Please (you,

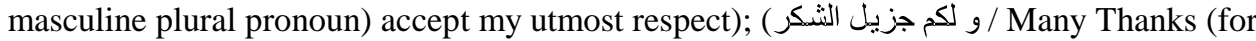
you, masculine plural pronoun)). These expressions correspond to the English concluding expressions of 'my kind regards', and/or 'yours sincerely'.

\subsubsection{System-Based, Culture-Bound and Religious Words and Expressions}

English legal discourse forms an integral part of the English Common Law and it is also a part of the English cultural background. On the other hand, Arabic legal discourse involves aspects of the Islamic Sharicah Law, and Civil Law. It is also affected by the customs and traditions of the Arabic countries. Accordingly, lexical items of different cultures may have different functions and meanings. Examples from the English Legal system are 'The House of Commons', 'Case Law', and 'Shadow Cabinet'. ${ }^{11}$

The Arabic official documents analyzed (i.e. marriage or divorce certificates) involve Islamic elements such as reference to God at the beginning of the certificate: (الحمد له / praise be to God) Within the certificate, the Hijri calendar is used and some

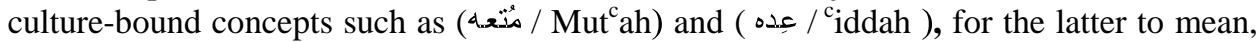
as Bahmeed $(2008,6)$ puts it, 'a period during which a Muslim woman usually keeps at home and does not use make-up or perfume to beautify herself. 130 days for the woman whose husband passed away and about 90 days for the divorcee.' There are numerous other examples of words which are specific to Islamic Jurisprudence with no equivalence in English. One of these words, among many others, is the word (خُلع-divorce). Because 'concepts have meanings only by virtue of being embedded in socio-culturally determined frames which are more or less culture-specific' as Schäffner, $(1997,137)$ believes, and because 'a message may be totally distorted if the implicit culture-specific information or culture-specific word meaning or an allusion is not grasped by the translator' (ibid), translation of such an Islamic term demands paraphrase to correspond directly and accurately to the SL word and render its connotations to the TL reader.

\footnotetext{
${ }^{11}$ Matulewska (2007:130-1) points out that 'in English legal instruments it is still common to encounter religious elements. The most popular phrases which indicates a religious character are the following: (i) acts of God, (ii) ... in the name of our Lord ..., (iii) in the year of our lord on thousand nine hundred and eighty-four'
} 


\section{Comparative Legilinguistics 4/2010}

Cultural and religious terms are common in local Arabic legal documents such as contracts and particularly in marriage and divorce contracts.

\subsubsection{Gender - Biased Terms}

Gender-bound words are very crucial to the analysis of legal discourse especially in the case of legal Arabic. It is not considered a prominent feature of English discourse, thus will not be discussed in English.

Baker $(1992,92)$ notes that in Arabic 'gender distinctions are reflected in nouns and pronouns but also in the concord between these and their accompanying verbs and adjectives'. Legal Arabic uses words that are marked for masculine. Many of these words exist in the official local documents such as contracts. One can find words such as ، ( / the landlord, the tenant (masc.), the contracted party (masc.), and the witness (masc.), respectively). Consider the following examples from Hatim, Shunnaq and Buckley (1995, 174-175):

$$
\text { يباشر المتعاقد واجبات وظيفة سكرتير لغات أجنبية في مقر الوزارة أو فروعها }
$$

The contracted party shall carry out the duties of Foreign Languages Assistant in the headquarters or the branches of the Ministry. (Employment Contract).

Here is another example from a Tenancy Agreement:

$$
\text { شاهد شاهد الثروتأجر تم الإتفؤجر و قبول الطرفين بتاريخ ... }
$$

These terms and conditions have been agreed upon and accepted by both parties on

Witness Witness Lessor Lessee

(Hatim, Shunnaq and Buckley 1995, 174-175)

According to the above example, the contract refers to male parties only and excludes any potential landladies or female tenants or even witnesses. It is true that sometimes one can figure out from the text that the witness, the lessee or the lessor is masculine as in the first example above. The word ( المتعاقد / the contracted party) refers to a male because the word (سكرتير / secretary), which is masculine, refers back to it. At the same time, the word ( / secretary) was translated as a gender-neutral word (Foreign Languages Assistant).

\subsection{Syntactic Features}

This section deals with the syntactic features of English and Arabic legal discourse; namely, passivization, nominalization, complex sentences and conditionals, performative verbs and modal auxiliaries, doublets and triplets, among others.

\subsubsection{Passivization}

According to Fowler (1991, 77), passive transformation includes a shift of positions of the left-hand and right-hand noun phrases. As a result, the patient (object) occupies the agent position. The passive is used for a number of reasons: (i) if a writer chooses the active voice in a sentence, s/he wants to focus on the agent of the action, (ii) but if $\mathrm{s} / \mathrm{he}$ chooses a passivized verb, s/he focuses on a part that $\mathrm{s} / \mathrm{he}$ sees more prominent, (iii) also, s/he may want to foreground a fact by leaving it unspecified. Tiersma $(1999,75)$ comments on nominalization and passivization as attributes that are 
imprecise which 'often obscure the identity of the actor; whether done intentionally or not, it can only reduce precision'. The example below gives some passive structures from A Report to the Court:

It was stated', 'a report be obtained from a different specialty', 'the injuries were examined', 'he was advised', 'it was recommended', 'he is waiting to be seen'.

Because Legal Arabic seeks accuracy and precision through avoiding obscurity of agents, it favours active to passive. A clear example is the shift in translating passive into active in the Arabic rendition of English legal texts as it is the case in translating the international documents. Consider the following instance:

The expenses of the Organization shall be borne by the Members as apportioned by the General Assembly. (Charter of the UN, article 17)

يتحمّل الأعضاء نققات الهيئة حسب الأنصبة التي تقرّر ها الجمعية العامة

(Charter of the UN, article 17)

Nowadays, this attitude has changed and a tendency to use passive has begun, albeit basic and inconsistent. The following example is cited in The Constitution of the Hashemite Kingdom of Jordan (article 13):

لا يُؤجز الثخص المدكوم عليه الي اثخاص ... أو يُوضع تحت تصرفها.

no convicted person shall be hired to , or be placed at the disposal of, any persons ...

\subsubsection{Nominalization}

By nominalization is meant 'a noun phrase that has a systematic correspondence with a clausal predication which includes a head noun morphologically related to a corresponding verb' (Quirk et al. 1985, 1288). It is reduced in the sense that some of the meaning one gets in a sentence is missing a tense, so there is no indication of the timing of the process; modality, and often an agent and/or a patient. This is an example from $A$ Deed:

He should guarantee or return anything from them according to the laws, regulations, statements, instructions, or declarations followed whether this regaining or surety ship is worthy of punishment or not and that this punishment has been confirmed by his confession, through investigation with him or according to official regulations or any other ways.

All the above italicized words are examples of nominalized forms. Although nominalization obscures the agent and the patient, and the avoidance of which is a must when uncertainty arises, it is useful in cases where the drafter wants to make laws 'to be stated as broadly as possible' (Tiersma 1999, 78).

Nominalization or more accurately, the verbal noun frequently occurs in Arabic legal discourse $^{12}$. The following is an example of such occurrence. Here is another instance of the preamble of The Egyptian Constitution:

${ }^{12}$ It is worth mentioning that the nominal form of the verb is also frequent in other genres of Arabic such as media discourse, and political discourse. Holes (2004: 314-324) lists the common features of Arabic news discourse. Among the syntactic features that Holes pointed out is nominalization. 


\section{Comparative Legilinguistics 4/2010}

نحن جماهير شعب مصر تصميما ويقينا و إيمانا و إدر اكا بكل مسئولياتنا الوطنية و القومية و الدولية.

We the working masses of the people of Egypt - out of determination, confidence and faith in all our national and international responsibilities. (my translation)

\subsubsection{Complex Sentences and Conditionals}

The English legal language is known for its extraordinary long and complex sentences. An English legal sentence is twice as long as the scientific English sentence. The longer the sentences, the more complex they are, the bigger the number of subordinating clauses and phrases. Consider the following excerpt cited in A Partnership Contract: (article 45):

The Contractor shall implement and maintain appropriate technical and organizational measures so as to prevent the destruction, damage, loss or alteration of the Data or the unauthorized or unlawful processing of the Data as agreed with the council and the Contractor shall provide the Council with such information as it may require to satisfy itself that the Contractor is complying with such obligations including but not limited to a copy of its registration under the Act and shall permit any authorized representative of the Council to have access to any site at which Data is stored to monitor the implementation, operation or existence of such procedures.

The above excerpt is an example of a 106-word sentence marked by one full stop at the end of it. The verbs in italics show the approximate number of clauses included in the sentence whether (i) independent, i.e. 'The Contractor shall implement and maintain appropriate technical and organizational measures', (ii) dependent, i.e. 'that the Contractor is complying with such obligations', (iii) or infinitival, i.e. 'to have access to any site'. There is also a high frequency of nominalized forms: 'destruction, damage, loss or alteration, etc.', not to mention the long lexical chains: '...to prevent the destruction, damage, loss or alteration of the Data or the unauthorized or unlawful processing of the Data'. This variety of clauses results in a compound complex sentence that consists of a mixture of coordinating conjunctions such as 'and', 'as', 'so as to', and subordinating conjunctions such as the relative pronouns 'that' and 'which'. It should be noted that this sentence, though long as it appears compared to modern English sentences of other text types, it is shorter than old legal sentences which used to reach a maximum of 250 words.

Complex conditionals and hypothetical formulations are commonly used in legal English. They are sometimes presented as parenthetical clauses. Examples of the syntactic indicators of condition and hypothesis are: 'if, 'where', 'whenever', 'provided that', 'assuming that', 'so long as', 'should'. The following instance is quoted from The Preamble of Universal Declaration of Human Rights:

Whereas recognition of the inherent dignity ... Whereas disregard and contempt for human rights have resulted in barbarous acts ... Whereas it is essential, if man is not to be compelled to have recourse ...Whereas it is essential to promote the development of friendly relations between nations, Whereas the peoples of the United Nations have in the Charter reaffirmed their faith in fundamental human rights ... Whereas Member States have pledged themselves to achieve, in cooperation with the United Nations ... Whereas a common understanding of these rights and freedoms is of the greatest importance for the full realization of this pledge, Now, 
therefore, The General Assembly, Proclaims this Universal Declaration of Human Rights.

Although it is a common feature of Arabic is to favour coordination through the conjunction

( 9 - and), legal Arabic displays complexity by using embedded and relative clauses initiated by one of the relative pronouns (الني ، الذي / who, whom, which, that). One of these instances is quoted form The Constitution of the People's Democratic Republic of Algeria:

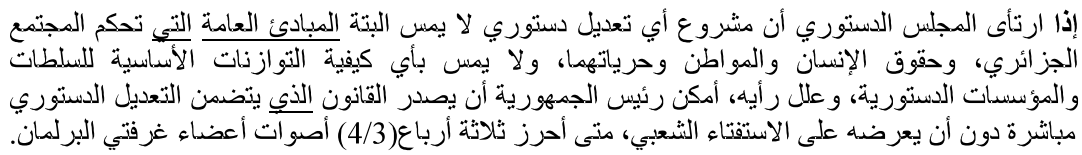

When the Constitutional Council considers that the draft constitutional revision does not infringe, at all, upon the general principles governing the Algerian society, the human and citizen's rights and liberties, or does not affect, in any way, the fundamental balance of powers and of institutions, the President of the Republic may promulgate, directly, the law pertaining to constitutional revision without submitting it to people's referendum if it obtains the voices of three quarters (3/4) of the members of the two chambers of the Parliament. (Article 176)

The above example also represents another feature of complexity of the Arabic legal sentence: conditional structures, introduced by (اذا / if, when) which are bold faced in the two texts. Parenthetical clauses and phrases also exist in legal texts. This means adding an explanatory clauses or phrase after a subject or an indirect object.

\subsubsection{Perfomative Verbs and Modals}

Language used in the law performs certain acts, mainly, declaring a right, making a prohibition, or giving permission, etc. This can be achieved through performative verbs (i.e. declare, authorize, enact, etc) as in the following instances:

I ...hereby authorize the following marriage certificate (Marriage Certificate)

I confirm that insofar as the facts in my report are within my own knowledge I have made clear which they are and I believe them to be true... (Report to the Court)

For Kurzon $(1986,16)$, speech acts occur with 'may' or 'shall' or their negative forms. In this case the whole sentence has an illocutionary force of permission (may), ordering (shall), or prohibition (shall not). 'Shall', for instance, is the most common and formulaic predominant form in legal texts in general and in legislative texts in particular. It dates back to the English translations of Roman law texts. 'Magna Carta' was described as 'an exercise in shall' (Šarčević' 1997, 138). It is stronger than 'must' in the sense that it guarantees that the action will occur. 'It unambiguously indicates that something is intended to be legally binding' (Tiersma 1999, 106). Consider the following example: 


\section{Comparative Legilinguistics 4/2010}

All members shall fulfil ... All members shall settle ... All members shall refrain ... All members shall give ... All members shall ensure ... (Charter of the UN, article 2)

Arabic, like English, uses performative verbs for the same purposes mentioned earlier. Some of these verbs are (أعلن / / إنظر / declare) and prohibited). The Arabic modal system is different from its counterpart in English. So, we are not speaking about modal verbs, we are speaking about modal expressions. (Sulieman 1999).

Based on the analysis of a collection of Arabic legal documents, the most frequent lexical modal verbs are (يجوز- may, يجب - must); prepositions and particles are

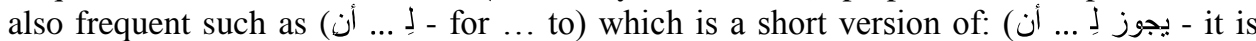
allowed for (somebody(ies) to (أن - en .... to) which is an abbreviated version of

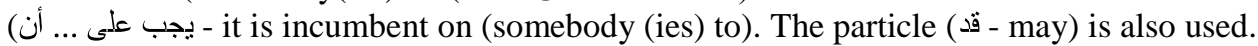
All these forms correspond to the English modal verbs: (shall, must, may) and these verbs, among some other less frequent forms take an imperfect clause initiated with (أن an) or as Abdul-Raof puts it 'a verb-first sentence' (2001, 35). The following is an example of modal verbs which is quoted from The Egyptian Labour Law:

يجب أن يتم الأخطار قبل الإنهاء بشهرين. (Article 111)

The notification shall be given two months before terminating

لا يجوز تعليق الإخطار بالإنهاء علي شرطو اقف أو فاسخ. (Article 112)

The notification terminating the contract shall not be made contingent on an abrogating or suspending condition.

\subsubsection{Doublets and Triplets}

Doublets and Triplets are also called 'binomial expressions' (Danet, 1985, 283); 'word-pairs', or 'conjoined phrases' Tiersma $(1999,44)$. They are defined (Danet 1985, 283) as 'sequences of two words belonging to the same class, which are syntactically coordinated and semantically related'. Such expressions are one way of using parallel structures. According to Tiersma (1999), a juxtaposition of two or may be three words is known as doublets or triplets. Danet $(1985,280)$ comments that these pairs are 'frozen expressions which are irreversible; they are formal syntactic features rather than lexical ones.' The UDOHR presents a good example of this syntactic category. Following are a number of these instances:

The General Assembly Proclaims this Universal Declaration of Human Rights as a common standard of achievement for all peoples and all nations; no one shall be held in slavery or servitude; no one shall be subjected to torture or to cruel, inhuman or degrading treatment or punishment; no one shall be subjected to attacks on his honour or reputation; everyone has the right to freedom of peaceful assembly and association. (UDOHR, preamble, and articles $4,5,12$, and 20 subsequently)

Arabic legal texts involve two or three words of related meanings, sometimes synonymous or near-synonymous which are conjoined by ( $g$ - and) or (و - or). These are called by Badawi et al. (2004, 138) 'binomials or polynomials'; 'hendiadys' (Al-Qinai 1999, 244); 'synonym couplets' (Williams 1989, 62); and 'dyadic couplets' (Koch - cf. Williams 1989, 62). Consider the following example of a doublet, cited from A Tenancy Agreement: 
يُفسخ هذا العقد فوراو تلقائياو بدون تنبيه أو إنذار في حالة... Article 12) This contract revokes immediately without any prior notice if ... (my translation)

These are also cited in a Marriage Contract:

و لا يحق لأي طرف النكول و التقاعس عن التزامه تجاه الطرف الأخر

No Party is allowed to neglect or delay his commitment to the other party. (my translation)

Here is one more example cited in The Preamble of the Egyptian Constitution:

الامكانيات و الملكات الخلاقة و المبدعة لثعبنا

... potentials of creativity and originality in our people.

$\ldots$ and to continuously rectify its path.

وأن يصدح دو اما وباستمز ار مسارها

Here is an example of a triplet cited in A Contract of Lease:

و هو مصدق في قوله من جهة وجود العيب و التلف و الخلل و بمقدار ما أنفق ...

The Lessor is deemed to be trustworthy in his account of the fault, the harm or the

damage, and the cost of repairing these ... (Hatim 1995, 186-187)

The above examples show that doublets are repeated in Arabic legal texts. This might be because of Arabic general tendency to favour simple listing.

\subsection{Other English Syntactic Features}

There are other syntactic features of legal discourse in English and Arabic which we will discuss briefly for word-count limitations. English is characterized by whdeletion in which words starting with 'wh' are dropped. These grammatical forms are repeated in contracts for which many instances are sited in A Partnership Contract, namely, 'premises made available, notices given, risks assumed, obligations assumed, and the times required, and assistance required' (pp: 24, 23, 26, 27, 27, 28 subsequently).

Prepositional phrases are another syntactic feature of English Legal discourse, such as 'pursuant to' (marriage certificate), 'without prejudice' (report to court, partnership contract), 'in accordance with', and 'prior to', 'in respect of', 'subsequent to', (partnership contract). These phrases are more frequent in contracts than in any other legal texts.

Similarly, legal language utilizes restrictive connectors like 'notwithstanding', 'under', 'whereas', and unique determiners such as 'said' as in 'aforesaid' 'such' as in 'a penalty as such', and 'subject to' as in 'subject to clause 7 overleaf, to keep the drains, gutters and pipes of the property clear...' (Tenancy Agreement, article 2).

Negative and double negative also occur in legal English. They are expressed either in 'not', 'never', in negative prefixes such as 'un' or in words like 'unless' and 'except'. Consider the following example:

He was not unduly nervous. (Report to the Court , p.3) 


\subsection{Other Arabic Syntactic Features}

There are some other grammatical features in Arabic legal texts, such as the passive participle, and the absolute object, or cognate accusative as Ryding (2005, 83) calls it. The passive participle is commonly used in impersonal sentences since they obscure the direct object. Like the present participle, they are dealt with as nouns and adjectives as they have a plural form. Consider the following example from The Constitution of The Hashemite Kingdom of Jordan :

تدمي الدولة حرية القيام بشعائر الأديان والعقائد طبقا للعادات المزعية في المملكة ما لم تكن مخلة بالنظام

(Article, 14)

The State shall safeguard the free exercise of all forms of worship and religious rites in accordance with the customs observed in the Kingdom, unless such is inconsistent with public order or morality. (Article, 14)

The absolute object is a repetition of the same verb in its verbal noun in order to focus more on the verb. It is also used in Arabic legal texts and it is one of the cohesive features of root repetition which will be discussed later in this chapter. The following two instances exemplify the absolute object in Arabic legal discourse.

Operating it effectivelly (Mansoor 1965b,129)

(Mansoor 1965a, 289) (إدارتها إدارة فعاله

قد عاينت القدر المباع محل التعاقد المعاينة التامة الذافية للجهالة

(Primary Contract for Sale)

She has completely viewed, without any negligence on her behalf, the sold part, as stated in this contract (my translation)

\section{Conclusion}

The boundaries between MSA and legal discourse are fuzzy. Some Legal Arabic genres such as legislative and international documents share some lexical and syntactic features with other Arabic genres such as diplomatic, political, media, and literary Arabic.

Formality in Arabic is expressed through pompous expressions which are also common in other genres of Arabic discourse (i.e. media discourse and diplomatic discourse).

English Legal language tends to be complex and it has been criticized for that since the $16^{\text {th }}$ century up to recent time. A tendency to use plain language has already begun and modern legislations nowadays are rewritten in a way that appeals to the layman, though not as easy as it seems. English Syntax is much more complex than its lexical features; it is even more complex than Arabic syntax.

There are some similarities between English and Arabic legal discourse. On the lexical level, these include formal words though the form and purpose for both is different.

On the syntactic level, English and Arabic legal discourse are characterized by nominalization, complexity through the length of sentences, the excessive use of 
subordinating and coordinating conjunctions, relative clauses, parenthetical phrases, and conditionals. They also are characterized by the use of doublets and triplets.

Differences between English and Arabic legal discourse on the lexical level involve archaic words, Latinisms, and French words which exist in English and do not form a part of the Arabic lexis. Pompous words are a distinctive feature of the Arabic legal genres whereas it does rarely exist in their English counterparts. Similarly, due to the difference of the legal systems, system-based words differ and they do not have direct correspondences. Arabic for example uses words which are based on Shari ${ }^{\mathrm{c}}$ ah law while English uses words which are based on Common Law. This results in the existence of religious words and concepts as well a culture- bound elements which exist in Arabic legal documents and are totally alien to its English counterpart.

Gender-Biased Terms are not prominent in legal English since neutral words are used. Legal Arabic, on the contrary, is characterized by the use of words that are marked for masculine.

On the syntactic level, there are some elements of differences between English and Arabic legal discourse such as passivization where the former frequently uses passive constructions although they are more frequent in some text types than others. Legal Arabic favours the active to the passive.

Modal auxiliaries are another area of difference between English and Arabic legal discourse. The former is characterized by a well-defined set of deontic modals while the latter refers to deontic modal expressions rather than verbs. These can be lexical verbs, prepositional phrases, particles, or even normal verbs in the imperfect mood.

There are other syntactic features which are specific to legal English such as the use of prepositional phrases, restrictive connectors, and double negative, and wh-deletion. Likewise, Arabic has some specific syntactic features which are not features of legal English such as the passive participle, and the use of absolute objects.

Based on the areas of differences outlined above, the most problematic areas of legal translation are (i) the culture-bound, system-based, and religious terms, archaic words and gender-biased words on the lexical level; (ii) passive, and modality on the syntactic level.

\section{Recommendations and Constraints}

For a whole image of the comparison between English and Arabic legal discourse, analysis of the textual features is required. Such analysis as well as lexical and syntactic features can also be done through corpus-based tools. It can also be applied to different legal genres. Yet, there are some constraints for using corpus analysis in the case of Arabic legal discourse. That is, Arabic legal corpus-based studies are rare and the only legal corpus available is not a $100 \%$ legal register. Moreover, a further look at the areas of difference between English and Arabic legal discourse is needed. It can be done through checking how these problematic areas have been rendered and what the techniques of adaptations have been used to render them.

\section{Bibliography}


Abdul-Raof, Hussein. 2000. Arabic Stylistics: A Course Book. Wiesbaden: Harraso Witz. Alcaraz, varó, Enrique and Brian, Hughes. 2002. Translation Practices Explained, Legal Translation Explained. Manchester: St. Jerome.

Alexy, Robert. 1989. A Theory of Legal Argumentation: The Theory of Rational Discourse as Theory of Legal Justification. Oxford: Clarendon Press.

Al-Qinai, Jamal. 1999. Explication vs. Implication in English-Arabic Translation. Theoretical Linguistics 25: 235-255.

Asensio, M. Roberto. 2003. Translating Official Documents. Manchester: St Jerome.

Badawi, Elsaid, Carter, M.G and Gully, Adrian. 2004. Modern Written Arabic: A Comprehensive Grammar, London/New York: Routledge.

Baker, Mona. 1992. In Other Words. London/New York: Routledge.

Cao, Deborah. 2007. Translating Law. Clevedon: Multilingual Matters.

Charrow, V.R. and Crandall, J. 1978. Legal Language: What is it and What can do we about it?. The American Dialect Society Conference/Georgetown NWAVE Conference, Washington, D.C.

Charrow, V.R. et al. 1982. "Characteristics and Functions of Legal Language". In Sublanguage: Studies of Language in Restricted Semantic Domain, ed. Kittredge, Richard and John Lehrberger, 175-189. Berlin/New York: Walter de Grayter.

Charrow, R.P. and Charrow, V.R. 1979a. Comprehension of Standard Jury Instructions: A Psycologistic Approach. Columbia Law Review 79.

1979b. Making Legal Language Understandable: A Psycholinguistic of the Jury Instructions. Columbia Law Review 79.

Conley et al. 1978. The Power of Language: Presentational Style in the Courtroom. Duke Law Journal 78: 1375-99.

Conley, John M. and William M.O'Barr. 1998. Just Words: Law, Language and Power. Chicago: The University of Chicago Press.

Coulthard, Malcolm. and Johnson, Alison. 2007. An Introduction to Forensic Linguistics: Language in Evidence. London: Routledge.

Crystal, D. and Davy, D. 1969. Investigating English Style. London: Longman.

Danet, B. 1976. Language and the Construction of Reality in the Courtroom. Working Papers. Boston University. . 1980. Language in the Legal Process. Law and Society Review 14, no. 3: 447-564. 1985. 'Legal Discourse'. In Handbook of Discourse Analysis, ed. T.A. van Dijk, 273-291. London: Academic Press.

Ebeid, R. Y. and Young, M. J. L. 1976. Some Arabic Legal Documents of the Ottoman Period. Leiden: E.J. Brill.

Edzard, Lutz. 1996. Stylistic Elements in the Use of Arabic as Language of Diplomacy: Recent Developments in United Nations Context. Die Welt des Islams 36 no. 1: 25-58.

.1997. Language as a Medium of Legal Norm: The Topics of 'War and Peace' and 'Human Rights' in bi-and Multilateral Treaties with Arab States and Organizations'. In Edzard and Szyska (1997), Encounters of Words and Texts: Intercultural Studies in Honor of Stefan Wild, Hildesheim /New York: Georg Olms Verlag. 
.1998. Language as a Medium of Legal Norms: Implications of the Use of Arabic as a Language in the United Nations System, Berlin: Duncker and Humblot.

Erickson, B. et al. 1978. Speech Style and Impression Format in Court Setting: the Effects of Powerful and Powerless Speech. Journal of Experimental Social Psychology 14: 266-279.

Fowler, R. 1991. Language in News. Discourse and Ideology in the Press. London: Routledge.

Garre, Marrianne. 1999. Human Rights in Translation: Legal Concepts in Different Languages. Denmark: Copenhagen Business School Press.

Gibbons, John. 1994. Language and the Law. London/ New York: Longman. 2003. Forensic Linguistics: An Introduction of the Language in the Justice System. Oxford: Blackwell.

Goodrich, Peter.1987. Legal Discourse: Studies in Linguistics, Rhetoric and Legal Analysis. Macmillan Press.

Gustafsson, M. 1975. Some Syntactic Properties of English Law Langauge. Turku/ Finland: University of Turku, 4.

Haigh, Rupert. 2004. Legal English. London: Cavendish Publishing.

Hassan, Aboudi, J. 2005a. Repetition as a Means of Disambiguation, Turjuman 14, no 1: 85-111.

Hatim, Basil. 1994. English-Arabic-English Translation: A Practical Guide. Morocco: The King Fahd School of Translation.

Hatim, Basil and I. Mason. 1997. The Translator as Communicator. London/ New York: Routletledge.

Holes, Clive. 1984. 'Textual Approximation in the Teaching of Academic Writing to Arab Students: A Contrastive Approach'. In J. Swales and H. Mustafa (ed): English for Specific Purposes in the Arab World, Birmingham: University of Aston.

. 2004. Modern Arabic: Structures, Functions, and Varieties, Washington DC: Georgetown University Press.

Kittredge, Richard and John Lehrberger. 1982. Sublanguage: Studies of Language in Restricted Semantic Domain. Berlin/New York: Walter de Grayter.

Kurzon, Dennis. 1986. It is Hereby Performed: Explorations in Legal Speech Acts. Amsterdam/Philadelphia: John Benjamins Publishing Company.

Lataiwish, Muftah S. 1995. An Analysis of Literary Translation Arabic/English. UnPublished PhD Thesis: University of Glasgow.

Matulewska, Alexandra. 2007. Lingua Legis in Translation, Europaischer Verlag der Wissenschaften, Peter Lang.

Maley, Yon. 1994. 'The Language of the Law'. In Gibbons: Language and the Law. London New York: Longman.

Mansoor, M. 1965a. Legal and Documentary Arabic Reader (vol. 1), Leiden: E.J.Brill. 1965b. Legal and Documentary Arabic Reader (vol. 2), Leiden: E.J.Brill.

Mellinkoof, David. 1963. The Language of the Law, Boston: Little, Brown. 1983. 'The Myth of Precision and the Law Dictionary', UCLA. Law Review. $31: 423$. 


\section{Comparative Legilinguistics 4/2010}

Meredith, Clive, R. 1979. 'Some Notes on Legal English'. Meta 24, no. 1: 54-67.

Newmark, Peter .1982. Approaches to Translation, Oxford: Pergamon. .1988. A Textbook to Translation, London: Prentice Hall.

O’Barr, William, M. 1982. Linguistic Evidence: Language, Power and Strategy in the Courtroom. New York: Academic Press.

Palmer, F. R. 1990. Modality and the English Modals, London: Longman.

Quirk, Randolph, S. Greenbaum, G. Leech, and J. Svartvik. 1985. A Comprehensive Grammar of the English Language, London: Longman.

Ryding, Karin C. 2005. A Reference Grammar of Modern Standard Arabic. Cambridge: Cambridge University Press.

Šarčević, Susan. 1997. New Approach to Legal Translation. London/ Boston: Kluwer Law International.

Schäffner, Christina. 1997. 'Strategies of translating political Texts'. In Text Typology and Translation, ed. Trosborg, A. Amsterdam/Phliladelphia: John Benjamins Publishing Company.

Shunnaq, A. 2000. Arabic - English Translation of Political Speeches. Perspectives: Studies in Translatology 8, no. 3: 207-228.

Sulieman, Yasir. 1999. Arabic Grammar and Linguistics. Great Britain: Curzon.

Tiersma, Peter M. 1999. Legal Language. Chicago/London: The University of Chicago Press.

Trosborg, A. 1995a. Introduction: Special Issue on Laying down the Law-Discourse Analysis of Legal Institutions. Journal of Pragmatics 23, no. 1: 1-5.

. 1995b. 'Statutes and Contracts: An Analysis of Legal Speech Acts in the English Language of Law'. Journal of Pragmatics 23, no. 1: 31-53.

. 1997. Rhetorical Strategies in Legal Language: Discourse Analysis of Statutes and Contracts. Germany: Gunter Narr Verlag Tubingen.

\section{Appendix}

The following tables represent the frequency analysis of modal auxiliaries in The Charter of the United Nations and its counterparts in the same documents in Arabic:

\begin{tabular}{|c|c|c|c|c|}
\hline No & Modal Type & Number & Percentage \% & \\
\hline 1 & Shall + Active & 1118 & $44.19 \%$ & \multirow{2}{*}{$62.93 \%$} \\
\hline 2 & Shall + Passive & 50 & $18.72 \%$ & \\
\hline 3 & May + Active & 62 & $23.22 \%$ & \multirow[t]{2}{*}{$29.96 \%$} \\
\hline 4 & May + Passive & 18 & $6.74 \%$ & \\
\hline 5 & Might + Active & 3 & $1.13 \%$ & \multirow[t]{2}{*}{$1.13 \%$} \\
\hline 6 & Might + Passive & 0 & $0 \%$ & \\
\hline 7 & Will + Active & 5 & $1.87 \%$ & \multirow[t]{2}{*}{$3.00 \%$} \\
\hline 8 & "Will + Passive & 3 & $1.13 \%$ & \\
\hline 9 & Should + Active & 2 & $0.74 \%$ & \multirow[t]{2}{*}{$1.11 \%$} \\
\hline 10 & Should + Passive & 1 & $0.37 \%$ & \\
\hline 11 & Must + Active & 0 & $0 \%$ & $0.37 \%$ \\
\hline
\end{tabular}




\begin{tabular}{|l|l||l|l||l||}
\hline 12 & Must + Passive & 1 & $0.37 \%$ & \\
\hline \hline 13 & Is to + Active & 0 & $0 \%$ & $0.37 \%$ \\
\hline \hline 14 & Is to + Passive & 1 & $0.37 \%$ & \\
\hline \hline 15 & Is likely to & 3 & $1.13 \%$ & $1.13 \%$ \\
\hline \hline 16 & Total & $\mathbf{2 6 7}$ & $\mathbf{1 0 0} \%$ & $\mathbf{1 0 0} \%$ \\
\hline
\end{tabular}

Table (1): Frequency Analysis of Modal Auxiliaries in The Charter of the United Nations:

\begin{tabular}{|c|c|c|c|c|}
\hline No & Modal Type & Number & Percent & \multirow{3}{*}{$46.09 \%$} \\
\hline 1 & لـٍ .... أن & 44 & $38.26 \%$ & \\
\hline 2 & ليس لِ .... أن & 9 & $07.83 \%$ & \\
\hline 3 & يجوز & 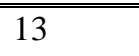 & $11.30 \%$ & \multirow[t]{2}{*}{$15.65 \%$} \\
\hline 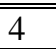 & لا يجوز & $\overline{5}$ & $04.35 \%$ & \\
\hline$\overline{5}$ & بجب & 14 & $12.17 \%$ & \multirow[t]{2}{*}{$12.17 \%$} \\
\hline 6 & لا بجب & 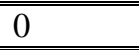 & $0 \%$ & \\
\hline$\overline{\overline{77}}$ & بينبغي & $\overline{33}$ & $02.61 \%$ & \multirow[t]{2}{*}{$02.61 \%$} \\
\hline 8 & لا ينبغي & 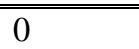 & $0 \%$ & \\
\hline 9 & قد & $\overline{15}$ & $13.04 \%$ & $13.04 \%$ \\
\hline$\overline{c 10}$ & على ... أن & $\overline{55}$ & $04.35 \%$ & $04.35 \%$ \\
\hline 11 & بحسب ما / حسبما & 3 & $02.61 \%$ & $02.61 \%$ \\
\hline 12 & من شأن & 2 & $01.74 \%$ & $01.74 \%$ \\
\hline 13 & بمكن أن & 1 & $0.87 \%$ & $0.87 \%$ \\
\hline 14 & من المهم أن & 1 & $0.87 \%$ & $0.87 \%$ \\
\hline 16 & Total & 115 & $100 \%$ & $100 \%$ \\
\hline
\end{tabular}

Table (2): Frequency analysis of modal expressions in the Arabic translation of The Charter of the United Nations.

\begin{tabular}{|c|c|c|c|}
\hline No & Modal Type & Number & $\begin{array}{l}\text { Percentage } \\
\%\end{array}$ \\
\hline 1 & لـ.... أن & 2 & $07.41 \%$ \\
\hline 2 & بجوز & 2 & $07.41 \%$ \\
\hline 3 & لا بجوز & 21 & $77.78 \%$ \\
\hline$\overline{44}$ & بجب & 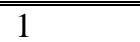 & $03.70 \%$ \\
\hline 5 & من الواجب & 1 & $03.70 \%$ \\
\hline$\overline{c 6}$ & Total & 27 & $100.00 \%$ \\
\hline
\end{tabular}


Table (3): Frequency analysis of modal expressions of the Arab Charter of Human Rights. 